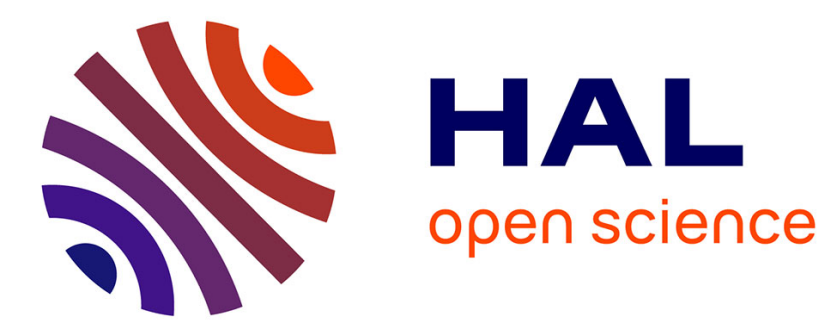

\title{
Forage soybeans (Glycine max (L.) Merr.) in the United Kingdom: test of new cultivars
}

Jason Koivisto, Thomas Devine, Gerry Lane, Charlotte Sawyer, Harvey Brown

\section{To cite this version:}

Jason Koivisto, Thomas Devine, Gerry Lane, Charlotte Sawyer, Harvey Brown. Forage soybeans (Glycine max (L.) Merr.) in the United Kingdom: test of new cultivars. Agronomie, 2003, 23 (4), pp.287-291. 10.1051/agro:2003001 . hal-00886180

\section{HAL Id: hal-00886180 \\ https://hal.science/hal-00886180}

Submitted on 1 Jan 2003

HAL is a multi-disciplinary open access archive for the deposit and dissemination of scientific research documents, whether they are published or not. The documents may come from teaching and research institutions in France or abroad, or from public or private research centers.
L'archive ouverte pluridisciplinaire HAL, est destinée au dépôt et à la diffusion de documents scientifiques de niveau recherche, publiés ou non, émanant des établissements d'enseignement et de recherche français ou étrangers, des laboratoires publics ou privés. 


\title{
Forage soybeans (Glycine max (L.) Merr.) in the United Kingdom: test of new cultivars
}

\author{
Jason M. KoIVISTO ${ }^{a *}$, Thomas E. Devine ${ }^{b}$, Gerry P.F. LANE ${ }^{a}$, Charlotte A. SAwYER ${ }^{a}$, Harvey J. BROwN ${ }^{a}$ \\ ${ }^{\text {a }}$ School of Agriculture, Royal Agricultural College, Cirencester, UK \\ ${ }^{\mathrm{b}}$ Sustainable Agricultural Systems Laboratory, Beltsville Agricultural Research Center, Agricultural Research Service, USDA, Beltsville, USA
}

(Received 29 April 2002; accepted 14 August 2002)

\begin{abstract}
Traditionally the soybean was used as a forage crop. Recently several cultivars and experimental lines have been bred for forage production. This coincides with the banning of meat and bone meal as a source of protein in ruminant diets in the European Union, which has led to a greater demand for high protein crops. Two USA bred cultivars, Derry and Donegal, were grown in a trial at the Royal Agricultural College in 2000 and 2001 to assess the viability of soybeans as a forage crop in the UK. In 2001 six experimental lines were added to the study. In 2000 dry matter yields ranged from 5.91 to $6.09 \mathrm{t} \cdot \mathrm{ha}^{-1}$ (Derry and Donegal, respectively) for the early harvest and 7.68 to $7.95 \mathrm{t} \cdot \mathrm{ha}^{-1} \mathrm{DM}$ (Derry and Donegal, respectively) for the late harvest. In the second season Donegal was the highest yielding at the early harvest with $12.1 \mathrm{t} \cdot \mathrm{ha}^{-1}$ and SG13\#169 had $12.1 \mathrm{t} \cdot \mathrm{ha}^{-1}$ at the late harvest. The proportion of leaf was not consistently associated with protein content. Across the two years the pod component did not exceed $110 \mathrm{~g} \cdot \mathrm{kg}^{-1}$. The experimental line SG13\#169 had the highest CP, $153 \mathrm{~g} \cdot \mathrm{kg}^{-1}$, and a yield of $8.51 \mathrm{t} \cdot \mathrm{ha}{ }^{-1}$ (at the first cut), and at the second harvest the CP fell to $146 \mathrm{~g} \cdot \mathrm{kg}^{-1}$, while the yield rose to $12.1 \mathrm{t} \cdot \mathrm{ha}^{-1}$. This more than offsetting the dilution of nutritional quality, by offering more $\mathrm{CP} \cdot \mathrm{ha}^{-1}$ from the late harvest. Additional testing is required for more conclusive evaluation of these experimental lines.
\end{abstract}

soybeans / Glycine max / forage / NDF / ADF / CP

Résumé - Soja fourrage (Glycine max (L.) Merr.) au Royaume-Uni. Traditionnellement le soja était utilisé comme culture fourragère. Récemment, plusieurs espèces ont été cultivées pour leur production fourragère dans le cadre de programmes de recherche. Ils coïncident avec l'interdiction des farines animales comme source de protéine dans l'alimentation des ruminants dans l'Union Européenne, qui implique une demande accrue de cultures protéagineuses. Un essai de culture de deux variétés des États-Unis, Derry et Donegal, a été mené au Royal Agricultural College en 2000 et 2001 pour évaluer la viabilité du soja comme culture fourragère au Royaume-Uni. En 2001, 6 expérimentations ont été ajoutées à l'étude. En 2000, les rendements de matière sèche étaient de 5,91 à $6,09 \mathrm{t} \cdot \mathrm{ha}^{-1}$ (Derry et Donegal, respectivement) pour la récolte précoce et de 7,68 à 7,95 t·ha ${ }^{-1}$ (matière sèche, Derry et Donegal respectivement) pour la récolte tardive. En seconde saison, Donegal était la variété à plus fort rendement pour la récolte précoce avec $12,1 \mathrm{t} \cdot \mathrm{ha}^{-1}$ et $\mathrm{SG} 13 \# 169 \mathrm{avec} 12,1 \mathrm{t} \cdot \mathrm{ha}^{-1}$ à la récolte tardive. La proportion de feuilles n'était pas corrélée de façon nette au contenu protéique. Au cours des 2 années, les composants de la gousse (CP) n'ont pas dépassé $110 \mathrm{~g} \cdot \mathrm{kg}^{-1}$. La ligne expérimentale sur SG13\#169 a obtenu la plus forte CP : $153 \mathrm{~g} \cdot \mathrm{kg}^{-1}$, et un rendement de $8,51 \mathrm{t} \cdot \mathrm{ha}^{-1}$ (à la première coupe), et à la seconde récolte, la CP est tombé à $146 \mathrm{~g} \cdot \mathrm{kg}^{-1}$, alors que le rendement atteignait $12,1 \mathrm{t} \cdot \mathrm{ha}^{-1}$. Cela fait plus que compenser la dilution de la qualité nutritionnelle par une offre de CP plus importante pour la récolte tardive. Des expériences complémentaires sont nécessaires pour une évaluation plus probante de ces recherches.

soja / Glycine max / fourrage / NDF / ADF / CP

\section{INTRODUCTION}

Since the banning of the use of most animal proteins in ruminant diets in the EU, there has been surge of interest in the production of various protein crops. Soybeans (Glycine max (L.) Merr.) were first introduced to North America and Europe as a forage crop [2]. In 1924, 405 thousand hectares of soybeans were planted for hay in the United States. Subsequently the area declined as a result of the crop being difficult to dry and the increasing value of soybean as a grain crop. Soybean is a crop that has only been grown occasionally in the United Kingdom. This is because only moderate yields have been 
obtained in the relatively cold climate of this country. As a result the crop has not been accepted for widespread commercial production. Robinson suggested [12] that the most likely role that soybeans would play in British agriculture was as a forage crop. He went on to suggest that the crop should be grown for 3 to 4 months, then harvested for silage. He also felt that it would be unrealistic to wait for the crop to develop pods, and that it should be harvested earlier because climatic conditions later in the season make fieldwork very difficult. He made reference to a field trial conducted in Shropshire 19251928 , where an average green fodder yield of $15.7 \mathrm{t} \cdot \mathrm{ha}^{-1}$ was harvested.

In recent years the USDA Agricultural Research Service has developed two new cultivars; Derry and Donegal [4, 5]. These cultivars have been specifically bred for forage production. Of the two cultivars being used in trials, Donegal is the cultivar that is most promising for UK conditions, being a maturity group V. Derry is a maturity group VI. Both Donegal and Derry have been proven in the United States, achieving yields of $10.9 \mathrm{t} \mathrm{DM} \cdot \mathrm{ha}^{-1}$ at $170 \mathrm{~g} \cdot \mathrm{kg}^{-1} \mathrm{CP}$ [1]. Nutritionally, whole crop soybeans provide similar levels of protein and digestibility to alfalfa $[7,10]$.

\section{MATERIALS AND METHODS}

\subsection{Field work}

Conventional tillage was used to prepare the seedbed. The soil on the experimental site was a well-drained, dark reddish brown, stony calcareous clay soil. In 2000 no supplemental P or $\mathrm{K}$ was used on the site, because of a high soil index for these nutrients. At planting, in both years, the seed was inoculated with an USDA patented Bradyrhizobium japonicum inoculum applied at a rate of $1 \mathrm{~g}$ per $100 \mathrm{~g}$ of seed. The site was sown on May 8th 2000, with a $1.5 \mathrm{~m}$ plot drill to a depth of $3.8 \mathrm{~cm}$ with $15 \mathrm{~cm}$ row spacing. The plot dimensions were $1.5 \times 5 \mathrm{~m}$ with seven replicates of each of the cultivars (Derry and Donegal) sown as a completely randomised design. The seed was sown at a rate of $50 \mathrm{seeds} \cdot \mathrm{m}^{-2}\left(500000 \mathrm{seeds} \cdot \mathrm{ha}^{-1}\right)$. The plots were sampled on two harvest dates (October 2nd and October 31st) taking three $25 \times 25 \mathrm{~cm}$ quadrat samples of forage from each of the 14 plots. These were then separated into leaves, stems and pods and their fresh weights recorded. The samples were dried at $80^{\circ} \mathrm{C}$, and the dry weights recorded.

In 2001, six experimental lines (provided by the Agricultural Research Service of the United States Department of Agriculture) were added to Derry and Donegal. All entries were sown on May 21st and 22nd in $18 \mathrm{~cm}$ rows to obtain a population of 70 seeds $\cdot \mathrm{m}^{-2}$. Individual plots were six rows wide by $3 \mathrm{~m}$ long, in a three replicate RCB design. $\mathrm{P}_{2} \mathrm{O}_{5}$ and $\mathrm{K}_{2} \mathrm{O}$ were applied at $80 \mathrm{~kg} \cdot \mathrm{ha}^{-1}$ and $120 \mathrm{~kg} \cdot \mathrm{ha}^{-1}$ respectively on June $5 \mathrm{th}$; $\mathrm{N}$ was applied at $50 \mathrm{~kg} \cdot \mathrm{ha}^{-1}$ on July 21 st. The crop was harvested on the 5 th of October and the 1st of November 2001. Samples were obtained by harvesting a $0.5-\mathrm{m}$ section of the center two rows of the plots. Samples were separated into stems, leaf-petiole, and pod; weighed, oven dried at $50{ }^{\circ} \mathrm{C}$, re-weighed for dry matter (DM), ground (1-mm) and subsequently analyzed for neutral detergent fibre (NDF), acid detergent fibre (ADF), and crude protein (CP). Mean air temperatures during the growing season were not atypical. Precipitation was typical except for a dryer period in June 2001, when supplemental irrigation was used.

\subsection{Laboratory analysis}

Crude protein was determined from plant nitrogen estimates from an adaptation to the Kjeldahl method (Gerhardt ${ }^{1}$ No. KJTH and GMV1). The nitrogen value obtained from the Kjeldahl method has to be multiplied by 1.4 to provide a conversation factor for total plant nitrogen, then multiplied by 6.25 to provide an estimate of crude protein $(\mathrm{CP})$. In turn $\mathrm{CP}$ yield was determined by multiplying $\mathrm{CP}$ concentration and total forage yield.

Before the fibre analysis the FibreBags were numbered, dried at $100{ }^{\circ} \mathrm{C}$ for 1 hour, desiccated for 5 minutes, and weighed. Sample dry weights for the ADF analysis were 0.65 to $0.75 \mathrm{~g}$, (weighed to $0.1 \mathrm{mg}$ ). Immediately after weighing the samples were placed into the corresponding FibreBag.

The FibreBags required a plastic insert to keep the bag open to allow the reflux action to work properly. The FibreBags were then placed in a carousel. These carousels were in turn placed in a 1000-ml beaker, with $360 \mathrm{ml}$ of acid detergent solution. The carousels were agitated in the solution to thoroughly wet the forage samples. The beakers were placed onto a heating element under a reflux condenser, and brought to a boil within 5 to 10 minutes. The heat was then reduced to maintain a gentle boil and boiled for $60 \mathrm{~min}$. After 30 minutes of boiling, the sides of the FibreBags were washed down using a syringe [8].

The FibreBags were rinsed in hot water $\left(95\right.$ to $100{ }^{\circ} \mathrm{C}$ ) to remove all of the detergent solution. The FibreBags were then removed from the carousels, and oven dried at $100{ }^{\circ} \mathrm{C}$ for 24 hours and re-weighed. The ADF and NDF concentrations were calculated in the manner detailed in [13].

The method for NDF analysis was identical to ADF with the exception of the sample size, for the NDF analysis the sample size was 0.45 to $0.55 \mathrm{~g}$, (weighed to $0.1 \mathrm{mg}$ ). Greater detail of this method of fibre analysis can be found in [9].

\section{STATISTICAL ANALYSIS}

All sets of data were subjected to randomized complete block and split plot analyses of variance with Genstat 5 release 4.2 [6]. Data for each year has been analyzed separately, because of variable weather conditions across the years of the study. Cultivar means were compared by using Fisher's Least Significant Difference (LSD) test [3].

\section{RESULTS AND DISCUSSION}

\subsection{0 season}

There were no significant differences in the yields of forage between the two cultivars of soybeans within or between the

\footnotetext{
${ }^{1}$ Gerhardt is a reference the manufacture of the digestion and distillation equipment used in this method. C. Gerhardt UK Ltd., Avonbury Court, Country Road, Brackley, UK NN13 7AX.
} 
Table I. Dry matter forage yields for Derry and Donegal soybeans at Cirencester, UK, in 2000.

\begin{tabular}{|c|c|c|c|c|c|c|c|}
\hline \multirow[b]{2}{*}{ Cultivar } & \multirow[b]{2}{*}{ Harvest date } & \multicolumn{6}{|c|}{ Mean value } \\
\hline & & Growth stage ${ }^{\mathrm{b}}$ & Yield & $\mathrm{DM}$ & Leaf & Stem & Pod \\
\hline & & & $-t \cdot h a^{-1}$ & 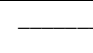 & $\mathrm{g}$. & 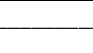 & - \\
\hline \multirow[t]{2}{*}{ Derry } & October 2nd & R 1 & $6.09 \mathrm{a}^{\mathrm{a}}$ & $216 \mathrm{a}$ & $654 \mathrm{a}$ & $346 \mathrm{a}$ & $0 \mathrm{a}$ \\
\hline & October 31 st & R 1 & $7.95 \mathrm{a}$ & $259 \mathrm{~b}$ & $656 \mathrm{a}$ & $344 \mathrm{a}$ & $0 \mathrm{a}$ \\
\hline \multirow[t]{2}{*}{ Donegal } & October 2nd & R 5 & $5.91 \mathrm{a}$ & $263 \mathrm{~b}$ & 638 a & $324 \mathrm{a}$ & $39 \mathrm{a}$ \\
\hline & October 31 st & R 5.5 & $7.68 \mathrm{a}$ & $289 \mathrm{~b}$ & $604 \mathrm{a}$ & $286 \mathrm{a}$ & $110 \mathrm{~b}$ \\
\hline
\end{tabular}

${ }^{\mathrm{a}}$ Means within the same column followed by different letters are significantly different at $P=0.05$.

${ }^{\mathrm{b}}$ Growth stages determined by using Ritchie et al. [7].

Table II. Analysis of variance for crude protein (CP), acid detergent fibre (ADF), and neutral detergent fibre (NDF) for two forage soybean cultivars grown at Cirencester, UK in 2000.

\begin{tabular}{|c|c|c|c|c|c|c|c|c|c|}
\hline & \multicolumn{3}{|c|}{$\mathrm{CP}$} & \multicolumn{3}{|c|}{$\mathrm{ADF}$} & \multicolumn{3}{|c|}{$\mathrm{NDF}$} \\
\hline & $\mathrm{df}(\mathrm{mv})$ & $\mathrm{MS}^{\mathrm{a}}$ & $\mathrm{F} \%$ & $\operatorname{df}(\mathrm{mv})$ & MS & $\mathrm{F} \%$ & $\mathrm{df}(\mathrm{mv})$ & MS & F \% \\
\hline Cultivar (C) & 1 & 43.6 & NS & 1 & 35059 & $<0.001$ & 1 & 99520 & $<0.001$ \\
\hline Plant fraction $(\mathrm{F})$ & 2 & 140557 & $<0.001$ & 2 & 323741 & $<0.001$ & 2 & 182146 & $<0.001$ \\
\hline Harvest $(\mathrm{H})$ & 1 & 743 & NS & 1 & 25270 & $<0.001$ & 1 & 28553 & 0.003 \\
\hline $\mathrm{C} \times \mathrm{F}$ & $1(1)$ & 7828.4 & $<0.001$ & $1(1)$ & 23 & NS & 1(1) & 7273 & NS \\
\hline $\mathrm{C} \times \mathrm{H}$ & 1 & 45 & NS & 1 & 970 & NS & 1 & 457 & NS \\
\hline $\mathrm{F} \times \mathrm{H}$ & $1(1)$ & 2 & NS & 2 & 8834 & $<0.001$ & 2 & 78698 & $<0.001$ \\
\hline $\mathrm{C} \times \mathrm{F} \times \mathrm{H}$ & $1(1)$ & 994 & NS & 1(1) & 18 & NS & 1(1) & 6672 & NS \\
\hline Residual & $36(19)$ & 299 & & $37(18)$ & 436 & & $36(19)$ & 2829 & \\
\hline
\end{tabular}

${ }^{\mathrm{a}}$ MS represents mean square; NS represents no significance.

two harvest dates. Donegal was at the R5 stage [11] of development and the Derry was at the R1 growth stage, at the early harvest. However the dry matter percentage of Donegal was $(P<0.05)$ higher than Derry (Tab. I). When comparing the plant constituents there were no significant differences between the percentages of any of the plant constituents, although Donegal had started to develop pods, and Derry was just flowering. This could have been due to different photoperiod requirements of the two cultivars. Donegal is a maturity group V soybean and Derry is a maturity group VI soybean [4, 5]. The photoperiod requirement for Donegal to set pods had probably been met earlier in the season.

High variability in the plots probably resulted in there being no significant differences in dry matter yields between harvests. The dry matter percentage of Derry sampled on the later date was significantly greater than on the earlier date. There was an $(P<0.05)$ increase in the percentage of pod for Donegal between the first and second harvests (Tab. I). In a quick visual evaluation of the roots at the time of both harvests, there appeared to be sufficient evidence of good nodulation.

The analysis of variance for the forage harvested in 2000 indicated a very significant difference in $\mathrm{CP}$ for plant fraction (Tab. II). There was no significant difference in CP due to cultivar or harvest effect. The level of CP in the stems was considerably lower than that found in the leaf and pod (Tab. III).
The analysis of variance for ADF indicated very highly significant differences due to cultivar, plant fraction, and harvest (Tab. II). Derry had a higher ADF value than Donegal. The ADF value was lower for the later harvest than the first harvest, particularly for the leaf and stem. The level of ADF for the stem fraction was higher than that found in the leaf and pod (Tab. III).

The analysis of variance for NDF indicated very highly significant differences due to cultivar, plant fraction, and harvest. Derry had a higher NDF value than Donegal. The NDF value at the later harvest was less than the NDF value at the first harvest for leaf and stem, but not pod fraction. The NDF values for stem were higher than for leaf or pod at the first harvest. They were also higher than for the leaf fraction at the second harvest. However, at the second harvest, the NDF value for pod was higher than the value for stem (Tab. III).

\subsection{1 season}

At the first harvest date, Donegal provided the highest yield of all the cultivars and experimental lines in this second year of the study (Tab. IV). Yield of Donegal was higher $(P<0.05)$ than the yields of Derry, $8 G H-66$, and $B L-15$. Dry matter yields were not related to the height of the crop. Specifically, the tallest line $(B L-15)$ had the lowest forage yield of any of 
Table III. Mean values for crude protein (CP), acid detergent fibre (ADF), and neutral detergent fibre (NDF) for two forage soybean cultivars across both harvests at Cirencester, UK in 2000.

\begin{tabular}{|c|c|c|c|c|c|c|}
\hline \multirow[b]{2}{*}{ Cut } & \multicolumn{3}{|c|}{ Donegal } & \multicolumn{3}{|c|}{ Derry } \\
\hline & Leaf & Stem & Pod & Leaf & Stem & Pod \\
\hline & \multicolumn{6}{|c|}{ NDF } \\
\hline & - & & 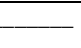 & $\mathrm{kg}^{-1}$ & & - \\
\hline October 2nd & 405.5 & 552.8 & 475.3 & 486 & 631.2 & 554.5 \\
\hline October 31st & 291.9 & 465.1 & 572.2 & 409.6 & 486.3 & 641.3 \\
\hline \multirow[t]{3}{*}{$\operatorname{LSD}(0.05)$} & 62.28 & & & & & \\
\hline & \multicolumn{6}{|c|}{$\mathrm{ADF}$} \\
\hline & 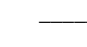 & 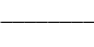 & - & $\mathrm{kg}^{-1}$ & 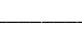 & - \\
\hline October 2nd & 185.1 & 439.4 & 269.9 & 224.5 & 473.5 & 306.7 \\
\hline October 31st & 142.5 & 354.5 & 262.9 & 194.1 & 405.8 & 314.7 \\
\hline \multirow[t]{3}{*}{ LSD (0.05) } & 24.42 & & & & & \\
\hline & \multicolumn{6}{|c|}{$\mathrm{CP}$} \\
\hline & \multicolumn{6}{|c|}{$-\mathrm{g} \cdot \mathrm{kg}^{-1}$} \\
\hline October 2nd & 194.9 & 89.6 & 222.9 & 211.4 & 73.2 & 222.8 \\
\hline October 31st & 180.5 & 94.1 & 218.2 & 212.1 & 56.4 & 214.9 \\
\hline LSD $(0.05)$ & 20.24 & & & & & \\
\hline
\end{tabular}

the cultivars at this harvest date. The highest crude protein (CP) value was $153 \mathrm{~g} \cdot \mathrm{kg}^{-1}$ for $S G 13 \# 169$, and the lowest was $100 \mathrm{~g} \cdot \mathrm{kg}^{-1}$ for $B L-38$. The higher protein value for $S G 13 \# 169$ was not a result of a higher leaf to stem ratio, because it was the same as $B L-38,1.55: 1 . S G 13 \# 169$ had $(P<0.05)$ lower levels of NDF than all experimental lines and cultivars except Donegal, which suggests that it would be more digestible, allowing for higher DM intakes. BL-38 and SG13\#169 had similar percentages of leaf, which were higher than Donegal and 97NYCZ-29. All other cultivars were between these extremes. There was no significant difference in the percentage of stem among any of the cultivars or experimental lines. Only two of the cultivars, Donegal and 97NYCZ-29, were sufficiently advanced in maturity to have developed pods. These two lines were not significantly different in pod development.

At the second harvest date Donegal and 97NYCZ-29 were the only two cultivars with pods. The only difference $(P<0.05)$ in DM yields at the second harvest was that $S G 13 \# 169$ was more than double the yield of Derry. However, when the average yields of the two harvest dates were compared Donegal, BL-38 and SG13\#169 $(P<0.05)$ out-yielded $8 G H-66, B L-15$ and Derry. The NDF and ADF concentrations increased $(P<0.05)$ from the first harvest date to the second

Table IV. First cut yields, stem height, dry matter, nutritional analysis, and composition of soybean cultivars and experimental lines at Cirencester, UK, 2001.

\begin{tabular}{|c|c|c|c|c|c|c|c|c|c|}
\hline Cultivar & DM Yield & Height & DM & $\mathrm{CP}$ & $\mathrm{ADF}$ & NDF & Leaf & Stem & Pod \\
\hline & $-\mathrm{t} \cdot \mathrm{ha} \mathrm{a}^{-1}-$ & $-\mathrm{cm}-$ & & - & 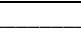 & $\mathrm{g} \cdot \mathrm{kg}^{-1}$ & & & \\
\hline \multicolumn{10}{|l|}{ October 5th } \\
\hline Donegal & 12.1 & 136 & 217 & 125 & 279 & 402 & 508 & 462 & 29 \\
\hline BL-38 & 11.9 & 130 & 221 & 100 & 318 & 455 & 608 & 392 & - \\
\hline $8 \mathrm{GH}-66$ & 7.2 & 97 & 177 & 133 & 341 & 448 & 585 & 415 & - \\
\hline BL-15 & 6.9 & 152 & 189 & 134 & 342 & 467 & 529 & 471 & - \\
\hline 97NYCZ-29 & 9.0 & 122 & 225 & 117 & 315 & 442 & 503 & 430 & 67 \\
\hline SG13\#169 & 8.5 & 93 & 178 & 153 & 297 & 384 & 608 & 392 & - \\
\hline Derry & 8.1 & 129 & 193 & 132 & 327 & 450 & 524 & 476 & - \\
\hline 7P116 & 9.0 & 85 & 211 & 137 & 303 & 434 & 593 & 407 & - \\
\hline Average & 9.2 & 116 & 202 & 129 & 315 & 435 & 557 & 431 & 12 \\
\hline$P \%^{\mathrm{a}}$ & NS & $* * *$ & NS & NS & NS & $* *$ & NS & NS & $*$ \\
\hline $\operatorname{LSD}(0.05)$ & 3.8 & 26 & 3.5 & 32 & 42 & 40 & 94 & 100 & 39 \\
\hline \multicolumn{10}{|l|}{ November $1 \mathrm{st}$} \\
\hline Donegal & 9.6 & 150 & 247 & 133 & 531 & 671 & 470 & 457 & 73 \\
\hline BL-38 & 10.3 & 156 & 235 & 127 & 598 & 738 & 503 & 497 & - \\
\hline 8GH-66 & 6.7 & 112 & 194 & 159 & 589 & 756 & 497 & 503 & - \\
\hline BL-15 & 6.5 & 156 & 221 & 136 & 635 & 787 & 430 & 570 & - \\
\hline 97NYCZ-29 & 9.6 & 124 & 244 & 125 & 560 & 684 & 437 & 457 & 107 \\
\hline SG13\#169 & 12.1 & 99 & 217 & 146 & 504 & 653 & 587 & 413 & - \\
\hline Derry & 5.2 & 155 & 202 & 155 & 641 & 825 & 443 & 557 & - \\
\hline 7P116 & 9.2 & 95 & 226 & 163 & 566 & 713 & 597 & 403 & - \\
\hline Average & 8.7 & 131 & 224 & 143 & 578 & 728 & 495 & 482 & 22.5 \\
\hline$P \%^{\mathrm{a}}$ & NS & $* * *$ & NS & NS & NS & $*$ & $* *$ & $*$ & $* *$ \\
\hline $\operatorname{LSD}(0.05)$ & 5.7 & 26 & 36 & 38.1 & 87.3 & 102.1 & 93.2 & 95.8 & 56.0 \\
\hline
\end{tabular}

${ }^{\mathrm{a}}$ Effect of cultivar or experimental line on the various constituents; NS: no significant effect; *, **, ***: 95, 99, 99.9\% significant. 
harvest date for all cultivars and experimental lines. There was an increase $(P<0.05)$ in CP from 128 to $143 \mathrm{~g} \cdot \mathrm{kg}^{-1}$ between the first and second harvest dates. The NDF values in November were very high and may suggest that the farmer should not wait this long to harvest. $97 N Y C Z-29$ appears to be earlier in maturity than Donegal and yet the percent leaf in November 2001 would suggest that it is not dropping its leaves, as might be the case with Donegal.

Based on the results from this study to date, several cultivars or experimental lines appear to be better suited to the southern UK than others. Donegal provided the largest single cut forage yield, and nutritionally it was one of the better cultivars. While there was a lower yield for $S G 13 \# 169$, it was not significantly different from Donegal. Other cultivars and experimental lines ( $8 G H-66$, Derry, and $B L-15)$ performed less well in this growing season. While this is the second growing season for the two cultivars (Derry and Donegal), this is only the first year of results for the experimental lines. Additional testing is required for more conclusive evaluation of these experimental lines. The study suggests that forage soybean could become a successful forage crop for UK conditions. Earlier harvests than were taken for this study would probably be advisable, but the crop shows useful potential for dry matter and crude protein yields.

The difference in yield between the years could be the result of soil fertility, but more than likely is the result of better weed control and a higher target-sowing rate in the second year. In 2001, it was decided to increase the sowing rate from $50 \mathrm{seeds} \cdot \mathrm{m}^{-2}$ to $70 \mathrm{seeds} \cdot \mathrm{m}^{-2}$. Mean air temperature in July 2000 was also $1.0{ }^{\circ} \mathrm{C}$ lower than the mean for either 2001 or the ten-year average. There was also $21 \mathrm{~mm}$ more precipitation over the months of June through August in 2001 than in 2000. The authors believe that combined these circumstances offers the most substantive argument as to why there was a yield difference between the years.

\section{REFERENCES}

[1] Borman K., Forage soybeans: A crop for the future. Missouri Soybean Farmer. March 1998 (Avail. on-line at http:// www.mosoy.org/mar98/forage.htm) (verified on August 2002).

[2] Caldwell B.E., Soybeans: Improvements, production, and uses, Agron. Monog. 16. ASA, CSSA, SSSA, Madison, 1973.

[3] Clewer A.G., Scarisbrick D.H., Practical Statistics and Experimental Design for Plant and Crop Science, John Wiley \& Sons Ltd., Chichester, UK, 2001.

[4] Devine T.E., Hatley E.O., Registration of 'Donegal' forage soybean, Crop Sci. 38 (1998) 1719-1720

[5] Devine T.E., Hatley E.O., Starner D.E., Registration of 'Derry' forage soybean, Crop Sci. 38 (1998) 1719.

[6] Harding S., Lane P., Murray D., Payne R., GenStat ${ }^{\circledR}$ for Windows (5th ed.) - Introduction, NAG, 2000.

[7] Hintz R.W., Albrecht K.A., Oplinger E.S., Yield and quality of soybean forage as effected by cultivar and management practices, J. Am. Soc. Agron. 84 (1992) 795-798.

[8] Kitcherside M.A., Glen E.F., Webster A.J.F., FibreCap: an improved method for the rapid analysis of fibre in feeding stuffs, Anim. Feed Sci. Tech. 86 (2000) 125-132.

[9] Koivisto J.M., Manley D., Comparing the effectiveness of fibrebags vs. fibrecaps for $\mathrm{ADF}$ and NDF analysis of forage legumes, Grassl. Sci. Europe (2002) 210-211.

[10] Ontario Ministry of Agriculture, Food and Rural Affairs. Field Crop Recommendations: 1997-1998, OMAFRA Publ. 296, Queen's Printer for Ontario, Toronto, 1997.

[11] Ritchie S.W., Hanway J.J., Thompson H.E., Benson G.O., How a soybean plant develops, Spec. Rep. 53, Iowa State Coop. Ext. Iowa State Univ., Ames, 1997.

[12] Robinson, D.H., Leguminous Forage Plants. Edward Arnold \& Co., London, 1947.

[13] Vogel K.P., Pedersen J.F., Masterson S.D., Toy J.J., Evaluation of a filter bag system for NDF, ADF, and IVDMD forage analysis, Crop Sci. 39 (1999) 276-279. 